Vol 1. No 2. Oktober Tahun 2021 e-ISSN : 2798-5466 P-ISSN : 2798-5725

\title{
PENERAPAN OBSERVASI TUTOR SEBAYA UNTUK MENINGKATKAN KEMAMPUAN AFEKTIF SISWA KELAS XI MIPA1 SMAN 2 TANJUNG JABUNG BARAT TAHUN 2019
}

\author{
SYAIDAH \\ SMA Negeri 2 Tanjung Jabung Barat \\ e-mail: syaidah096@gmail.com
}

\begin{abstract}
ABSTRAK
Jenis penelitian ini menggunakan penelitian tindakan kelas (Classroom Action Research) karena peneliti bertindak secara langsung dalam penelitian, mulai dari awal sampai akhir tindakan. Dalam penelitian ini, peneliti menemukan beberapa permasalahan afektif siswa di SMA Negeri 2 Tanjung Jabung Barat kelas XI MIPA1 antara lain: siswa tidak mengawali belajar dengan berdoa kecuali bila diingatkan terutama pada setiap pergantian jam pembelajaran, siswa kurang berani bertanya, menjawab atau menyampaikan pendapatnya tentang materi pembelajaran, siswa belum terbiasa mengucapkan atau menjawab salam, siswa kurang disiplin, terutama dalam kerapihan dan kebersihan berpakaian. Penelitian ini menggunakan metode Observasi Tutor Sebaya dimana siswa berperan sebagai subjek (pengamat) sekaligus sebagai objek (yang diamati). Perilaku yang diamati adalah sikap siswa yang telah dirancang peneliti dalam sebuah kartu observasi. Penelitian ini dilaksanakan sebanyak 2 siklus dengan 3 kali pertemuan. Hasil penelitian menunjukkan peningkatan di setiap siklusnya, yaitu pra siklus sebanyak 38\%, siklus I sebanyak 57\% dan siklus II sebanyak 93\%. Pembelajaran dengan penerapan metode Observasi Tutor Sebaya cukup efektif meningkatkan kemampuan afektif siswa di kelas XI MIPA1 SMA Negeri 2 Tanjung Jabung Barat.
\end{abstract}

Kata Kunci : Metode Tutor Sebaya, Penelitian Tindakan Kelas, Kemampuan Efektifitas

\section{PENDAHULUAN}

Belajar merupakan usaha sadar yang dilakukan individu untuk memperoleh berbagai kemampuan (competencies), keterampilan (skill), dan sikap (attitudes) melalui serangkaian proses belajar yang pada akhirnya akan menghasilkan perubahan tingkah laku pada individu tersebut. Perubahan tingkah laku yang diperoleh melalui proses belajar secara keseluruhan meliputi aspek kognitif, afektif, dan psikomotorik. Namun dalam prakteknya, proses pembelajaran di sekolah lebih cenderung menekankan pada pencapaian perubahan aspek kognitif (intelektual) yang dilaksanakan melalui berbagai bentuk pendekatan, strategi, dan model pembelajaran tertentu.

Sistem pembelajaran yang secara khusus mengembangkan kemampuan afektif kurang mendapat perhatian. Kemampuan afektif hanya dijadikan sebagai efek pengiring (nurturant effect) atau menjadi hidden curriculum, yang disisipkan dalam kegiatan pembelajaran yang utama yaitu pembelajaran kognitif atau pembelajaran psikomotor.

Beberapa ahli mengatakan bahwa sikap seseorang dapat diramalkan perubahannya, bila seseorang sudah memiliki penguasaan kognitif tingkat tinggi. Pada akhirnya, penilaian hasil belajar afektif kurang mendapat perhatian dari guru. Dalam menilai hasil belajar siswa para guru lebih banyak mengukur siswa dalam penguasaan aspek kognitif.

Mungkin pada KTSP penilaian afektif belum terlalu diperhatikan, namun seiring dengan dikembangkannya pendidikan karakter bangsa, penilaian afektif menjadi lebih penting dan harus dilakukan guru agar dapat diketahui keberhasilan pembelajaran yang dapat diwujudkan melalui internalisasi sikap yang ditunjukkan oleh peserta didik setelah mengikuti proses pembelajaran.

Pendidikan Agama Islam (PAI) sebagai salah satu mata pelajaran di sekolah mempunyai peranan yang sangat strategis dan signifikan dalam pembentukan karakter dan kepribadian siswa. Namun Pembentukan karakter yang diharapkan tidak akan maksimal jika guru 
mengenyampingkan penilaian pada ranah afektif siswa yang memuat minat, sikap, nilai, apresiasi dan penyesuaian.

Pada dasarnya, ranah afekti mempunyai hubungan dengan ranah kognitif yang mana setiap proses afektif terdapat komponen kognitif. Sebagai contoh, dalam proses belajar mengajar dibutuhkan "perhatian" siswa supaya siswa mudah menerima "pengetahuan". Jika siswa sudah memiliki "pengetahuan", maka siswa akan memiliki "kemauan" untuk menjawab pertanyaan guru. Begitu juga seterusnya, siswa mampu menilai baik dan buruk jika sudah memahami dan menganalisa fenomena tersebut.

Dengan demikian, dapat dipahami bahwa komponen-komponen di atas memang tidak bisa dipisahkan dari proses belajar mengajar. Namun di sini peneliti ingin menekankan pembelajaran pada aspek afektif siswa. Dalam penelitian ini, peneliti akan mengungkapkan permasalahan yang berhubungan dengan ranah afektif siswa di SMA Negeri 2 Tanjung Jabung Barat, Kecamatan Tungkal Ilir, Kabupaten Tanjung Jabung Barat.

Dari hasil pengamatan sebagai guru bidang studi PAI di sekolah tersebut selama 3 bulan, peneliti sering menemukan permasalahan sebagai berikut:

Pertama, Peneliti menemukan masih banyak siswa yang tidak mengawali belajar dengan berdo'a, kecuali setelah diingatkan. Berdo'a belum menjadi bagian karakteristik siswa dalam memulai atau mengakhiri sebuah pekerjaan. Disamping itu, siswa belum terbiasa mengucapkan salam. Jika ada siswa yang mengucapkan salam sebelum menyampaikan pertanyaan atau menjawab pertanyaan, siswa yang lain mentertawakan. Fenomena ini tentu harus dicarikan solusinya terutama oleh peneliti yang notabene adalah guru bidang studi PAI.

Kedua, dalam kegiatan belajar mengajar, peneliti menemukan masih banyak siswa yang belum berani bertanya, menjawab atau menyampaikan pendapatnya tentang materi yang disampaikan. Dari hasil pengamatan, keadaan tersebut dikarenakan beberapa hal, seperti rasa malu, takut salah, takut ditertawakan teman, takut dikira bodoh, tidak bisa menyusun kata-kata yang baik, dan sebagainya. Keadaan ini mendorong peneliti untuk mencari metode atau cara yang tepat untuk meningkatkan keberanian siswa dalam bertanya, menjawab atau menyampaikan pendapat, usul-usul, serta argumen lainnya.

Ketiga, selama menjadi guru bidang studi PAI, peneliti menemukan kesulitan dalam menerapkan kerapihan dan kebersihan pakaian pada siswa maupun siswi. Sebagai contoh, siswa merasa lebih nyaman dengan model baju dikeluarkan. Mereka tidak jera walau harus mendapat hukuman berkali-kali dari guru seperti push up, membersihkan WC, dan sebagainya. Sedangkan siswi muslimah yang diwajibkan berhijab (jilbab), masih belum benar cara menggunakannya, karena sebagian rambut mereka masih terlihat walaupun mengenakan jilbab. Fenomena ini mungkin terlihat sepele, namun sangat menentukan terbentuknya sikap disiplin dan karakter siswa yang taat peraturan dan religius. Karena itu, sebagai guru PAI, peneliti berusaha mencari metode pengajaran yang dapat membentuk karakter-karakter baik sebagaimana yang diharapkan.

Dari permasalahan di atas, sangat jelas tergambar bahwa ada permasalahan pada ranah afektif di SMA Negeri 2 Tanjung Jabung Barat. Karena itu peneliti mencoba merancang dan melakukan sebuah penelitian tindakan kelas. Kondisi yang ingin ditingkatkan dalam penelitian ini antara lain; (a) Membiasakan siswa untuk berdo'a sebelum dan sesudah kegiatan pembelajaran, (2) Membiasakan siswa untuk mengucapkan salam di dalam kelas khususnya, terutama ketika ingin memulai berbicara (bertanya, menjawab pertanyaan, atau berpendapat), (3) membiasakan siswa untuk menjawab salam, (4) Membiasakan siswa untuk bertanya, menjawab, atau menyampaikan pendapat (5) Membiasakan siswa berpakaian rapi dan bersih sesuai peraturan sekolah.

Berdasarkan grand tour di atas, peneliti mencoba melakukan sebuah metode pembelajaran yang berjudul: "Penerapan Metode Observasi Tutor Sebaya untuk Meningkatkan Kemampuan Afektif Siswa Kelas XI MIPA1 SMA Negeri 2 Tanjung Jabung Barat Tahun $2019 "$ 


\section{METODE PENELITIAN}

Jenis penelitian ini menggunakan penelitian tindakan kelas (Classroom Action Research) karena peneliti bertindak secara langsung dalam penelitian, mulai dari awal sampai akhir tindakan. Menurut Suharsimi (dalam Dila Candrawati, 2013: 32) bahwa PTK merupakan paparan gabungan defenisi dari tiga kata "penelitian, tindakan dan kelas". Penelitian adalah mencermati suatu objek, menggunakan aturan metodologi tertentu untuk memperoleh data atau informasi yang bermanfaat bagi peneliti atau orang-orang yang berkepentingan dalam rangka peningkatan kualitas di berbagai bidang. Dalam Iskandar (2011: 28), mengungkapkan bahwa proses pelaksanaan penelitian tindakan kelas ini didesain model dari Kemmis \& Mc. Taggart yang perangkatnya terdiri atas empat komponen, yaitu planning (perencanaan), action (tindakan), observing (pengamatan), dan reflecting (refleksi). Penelitian tindakan kelas memiliki beberapa karakteristik. Aqib (2009: 16) mengungkapkan ada lima karakteristik PTK, antara lain:

1. Didasarkan pada masalah yang dihadapi guru dalam instruksional.

2. Adanya kolaborasi dalam pelaksanaannya.

3. Peneliti sekaligus sebagai praktisi yang melakukan refleksi.

4. Bertujuan memperbaiki atau meningkatkan kualitas produk instruksional.

5. Dilaksanakan dalam rangkaian langkah dengan beberapa siklus.

Berdasarkan paparan di atas, dapat ditarik suatu kesimpulan bahwa PTK adalah penelitian yang dilakukan guru di dalam kelasnya sendiri melalui refleksi diri dengan tujuan untuk memperbaiki kualitas proses pembelajaran di kelas, sehingga hasil belajar siswa dapat ditingkatkan. Sedangkan dalam pelaksanaan PTK harus sesuai alur. Secara sederhana alur pelaksanaan tindakan kelas ini disajikan sebagai berikut:

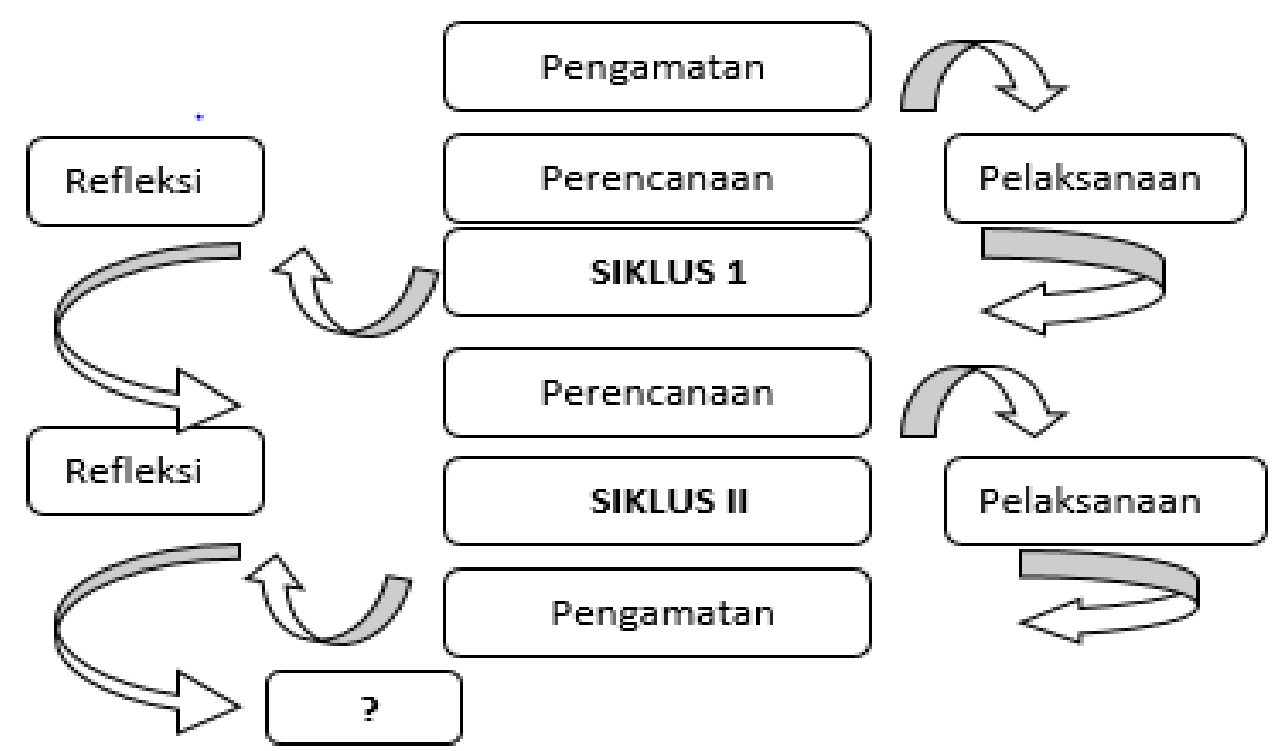

\section{Gambar 1. Alur Penelitian Tindakan Kelas model Kemmis \& Mc. Taggart|}

Dengan mengacu pada refleksi awal tersebut, maka dilaksanakan penelitian tindakan kelas dengan prosedur antara lain, Perencanaan (planning), Pelaksanaan Tindakan (action), Observasi (observation), dan Refleksi (reflection). Indikator keberhasilan tindakannya adalah meningkatnya kemampuan afektif siswa berdasarkan lembar observasi tutor sebaya yang telah dirancang oleh peneliti, dengan kategori persentase 20-39 (rendah), 40-59 (sedang), 60-79 (tinggi), 80-99 (sangat tinggi). 


\section{HASIL DAN PEMBAHASAN}

\section{Siklus I}

\section{Perencanaan Siklus I}

Pada tahap perencanaan, peneliti mempersiapkan perangkat pembelajaran yang terdiri dari; RPP pertemuan I, lembar observasi penilaian tutor sebaya, lembar instrumen observasi guru dan teman sejawat, laptop dan LCD, dan pedoman interview untuk siswa dan guru.

\begin{tabular}{|c|c|c|c|c|c|c|c|}
\hline \multicolumn{8}{|c|}{$\begin{array}{l}\text { Nama : } \\
\text { Kelas : }\end{array}$} \\
\hline \multirow{3}{*}{ 总 } & \multicolumn{7}{|c|}{ ASPEK YANG DINILAI } \\
\hline & \multicolumn{2}{|c|}{ Religius } & \multicolumn{3}{|c|}{ Keberanian } & \multicolumn{2}{|c|}{$\begin{array}{c}\text { Kedisiplinan } \\
\text { berpakaiam }\end{array}$} \\
\hline & Berdo'a & $\begin{array}{l}\text { Mengucapkan } \\
\text { Salam }\end{array}$ & $\begin{array}{c}\text { Menjawab } \\
\text { salam }\end{array}$ & Bertanya & $\begin{array}{c}\text { Menjawab/ } \\
\text { berpendapat }\end{array}$ & Rapi & Bersih \\
\hline 1 & & & & & & & \\
\hline 2 & & & & & & & \\
\hline Dst & & & & & & & \\
\hline
\end{tabular}

Gambar 2. Lembar observasi penilaian tutor sebaya

\section{Pelaksanaan Siklus I}

Pelaksanaan kegiatan belajar mengajar untuk siklus I dilaksanakan pada Sabtu, tanggal 20 Juli 2019 di kelas XI MIPA1 dengan jumlah siswa 27 siswa. Setiap siswa mengamati satu siswa lainnya dan menceklist setiap perilaku atau kegiatan yang dilakukan teman sebaya sesuai lembar observasi yang telah dirancang guru (peneliti). Sebelumnya data hasil pengamatan ranah afektif pra siklus I antara lain; berdoa dilakukan oleh 15 siswa (56\%), mengucapkan salam 7 siswa (26\%), menjawab salam 10 siswa (37\%), bertanya 5 siswa (19\%), menjawab pertanyaan/berpendapat 9 siswa (33\%), berpakaian rapi dan bersih 11 siswa (41\%). Kemudian data hasil pengamatan siklus I antara lain; berdoa 22 siswa (81\%), mengucapkan salam 12 siswa (44\%), menjawab salam 10 siswa (37\%), bertanya 12 siswa (44\%), menjawab pertanyaan/berpendapat 15 siswa (56\%), rapi dan bersih 17 siswa $(63 \%)$.

Berdasarkan data di atas dapat diketahui bahwa terjadi peningkatan hasil pembelajaran siswa pra siklus dan siklus I pada ranah afektif dengan penerapan metode observasi tutor sebaya, siswa SMA Negeri 2 Tanjung Jabung Barat kelas XI MIPA1.

\section{Refleksi Siklus I}

Dalam kegiatan belajar mengajar diperoleh informasi dari hasil pengamatan antara lain; guru kurang baik dalam memotivasi siswa, guru kurang baik dalam pengelolaan waktu, dan siswa belum antusias selama pembelajaran berlangsung.

\section{Revisi Siklus I}

Pelaksanaan pembelaaran pada siklus I masih terdapat kekurangan, sehingga perlu adanya revisi untuk dilakukan pada siklus berikutnya, antara lain;

a. Guru perlu lebih terampil dalam memotivasi siswa dan lebih jelas dalam menyampaikan tujuan pembelajaran. Siswa diajak untuk terlibat dalam setiap kegiatan yang sedang berlangsung.

b. Guru perlu mendistribusikan waktu secara baik dengan menambahkan informasi-informasi yang dirasa perlu dan memberi catatan-catatan. 
c. Guru harus bersemangat dalam memotivasi siswa sehingga siswa lebih antusias.

\section{Siklus II}

\section{Perencanaan Siklus II}

Pada tahap ini peneliti mempersiapkan perangkat pembelajaran yang terdiri dari RPP pertemuan 2, lembar observasi tutor sebaya, lembar instrumen observasi guru dan teman sejawat, laptop dan LCD, dan pedoman interview untuk siswa dan guru.

\section{Pelaksanaan Siklus II}

Pelaksanaan kegiatan belajar mengajar siklus II dilaksanakan pada Sabtu, tanggal 27 Juli 2019. Proses belajar mengajar mengacu pada rencana pembelajaran dengan memperhatikan revisi pada siklus I, sehingga kesalahan atau kekurangan pada siklus I tidak terulang lagi pada siklus II. Pengamatan dilaksanakan bersamaan dengan pelaksanaan belajar mengajar. Adapun data hasil pengamatan ranah afektif siswa pada siklus II antara lain; berdoa 27 siswa (100\%), mengucapkan salam 25 siswa (93\%), menjawab salam 27 siswa (100\%), bertanya 20 siswa (74\%), menjawab pertanyaan/berpendapat 23 siswa (85\%), rapi dan bersih 27 siswa (100\%).

\section{Refleksi Siklus II}

Dalam pelaksanaan kegiatan pembelajaran diperoleh informasi dari hasil pengamatan antara lain; guru memotivasi siswa dan membimbing siswa merumuskan/menemukan konsep, pengelolaan waktu dan revisi rancangan. Walaupun pada siklus II telah terjadi peningkatan kemampuan ranah afektif, seperti peningkatan pada aspek religius, keberanian, dan kedisiplinan, bukan berarti tidak ada kekurangan. Ada beberapa point yang perlu diperhatikan peneliti selanjutnya, antara lain;

a. Guru harus lebih memotivasi siswa dalam kegiatan belajar mengajar yang sedang berlangsung.

b. Guru harus lebih dekat dengan siswa sehingga tidak ada perasaan takut dalam diri siswa untuk bertanya atau mengemukakan pendapat.

c. Guru harus lebih sabar dalam membimbing siswa dalam merumuskan kesimpulan/menemukan konsep.

d. Guru harus mendistribusikan waktu secara lebih baik lagi. e.

\section{- Perbandingan Hasil Penelitian dan Kriteria Keberhasilan Penelitian}

Berdasarkan analisis hasil pengamatan keseluruhan dalam penelitian ini, maka pembelajaran dengan penerapan metode observasi tutor sebaya mengalami peningkatan pada pra siklus, siklus I dan sikus II, yaitu:

(1)Persentase kemampuan afektif siswa pada pra siklus sebesar $38 \%$, meningkat di siklus I (57\%), dan di siklus II (93\%).

(2)Persentase aspek religius mengalami peningkatan, yaitu; pra siklus sebesar 46\%, siklus I (54\%), dan siklus II (98\%).

(3)Persentase aspek Keberanian juga mengalami peningkatan, yaitu; pra siklus sebesar 26\%, siklus I (50\%), dan siklus II (80\%).

(4)Persentase aspek kedisiplinan mengalami peningkatan yaitu: pra siklus sebesar 34\%, siklus I (53\%), dan siklus II (100\%).

Berdasarkan data di atas dapat diketahui peningkatan kemampuan afektif siswa baik pada aspek relegius, aspek keberanian dan aspek kedisiplinan. Adanya peningkatan kemampuan afektif ini karena guru menginformasikan bahwa setiap pembelajaran PAI selalu dilakukan metode observasi tutor sebaya. Guru juga memberitahukan materi yang akan disampaikan pada pertemuan berikutnya, sehingga siswa lebih termotivasi untuk mempersiapkan beberapa pertanyaan yang berhubungan dengan materi tersebut. Disamping itu, siswa sudah mulai mengerti apa yang dimaksudkan dan diinginkan guru dengan menerapkan metode pembelajaran observasi tutor sebaya. 
Tabel 1. Rekapitulasi lembar pengamatan metode Observasi Tutor Sebaya pada pra siklus, siklus I dan siklus II

\begin{tabular}{|c|c|c|c|}
\hline NO & SIKLUS & $\begin{array}{c}\text { PERSENTASE } \\
\text { PENINGKATAN }\end{array}$ & KATEGORI \\
\hline 1 & Pra Siklus & $38 \%$ & Kurang \\
\hline 2 & Siklus I & $57 \%$ & Sedang \\
\hline 3 & Siklus II & $93 \%$ & Sangat Tinggi \\
\hline
\end{tabular}

Tabel 2. Rekaptulasi lembar pengamatan metode Observasi Tutor Sebaya pada aspek religius, keberanian dan kedisiplinan

\begin{tabular}{|c|c|c|c|c|}
\hline $\mathrm{N}$ & \multirow{2}{*}{ ASPEK } & PRA & SIKLUS & SIKLUS \\
$\mathrm{O}$ & SIKLUS & I & II \\
\hline 1 & Religius & $46 \%$ & $54 \%$ & $98 \%$ \\
\hline 2 & Keberanian & $26 \%$ & $50 \%$ & $80 \%$ \\
\hline 3 & \multirow{2}{*}{ Kedisipilinan } & $34 \%$ & $53 \%$ & $100 \%$ \\
\hline
\end{tabular}

\section{PERSENTASE PENINGKATAN}

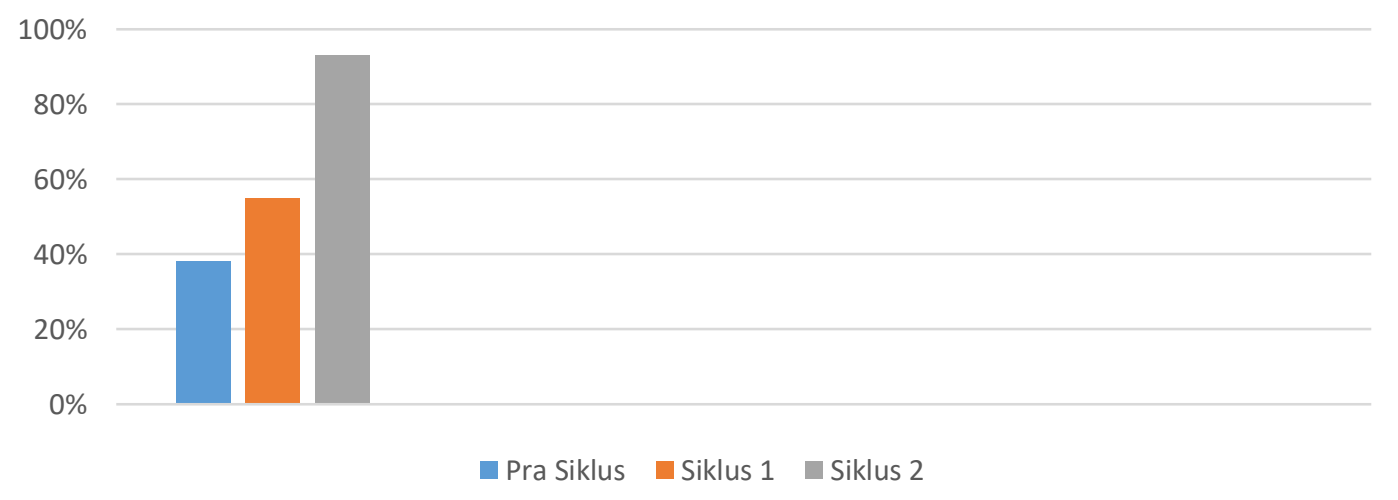

Gambar 3. Grafik Presentase Hasil Penelitian

\section{KESIMPULAN}

Dalam penelitian tindakan kelas ini, peneliti telah melakukan pembelajaran yang memenuhi beberapa kriteria, sebagai berikut:

1. Pembelajaran tidak hanya satu arah, tetapi multi arah. Guru berinteraksi kepada siswa, siswa berinteraksi kepada guru, dan siswa berinteraksi kepada siswa.

2. Berdasarkan hasil pengamatan guru, pembelajaran cukup menyenangkan.

3. Terjadi peningkatan di setiap siklus, yaitu siklus I dan siklus II meliputi aspek religius, aspek keberanian, dan aspek kedisiplinan.

4. Pembelajaran dengan penerapan metode observasi tutor sebaya cukup efektif meningkatkan kemampuan afektif siswa di kelas XI MIPA1 SMA Negeri 2 Tanjung Jabung Barat.

\section{DAFTAR PUSTAKA}

Aqib, Zainal. (2009). Penelitian Tindakan Kelas. Bandung: Remadja Rosdakarya.

Arikunto, Suharsimi. (2002). Prosedur Penelitian. Jakarta: Rineka Cipta.

Buchari Alam, dkk. (2009). Guru Profesional (Menguasai Metode dan Terampil Mengajar). Bandung: Penerbit Alfabeta. 
Bungin, Burhan. (2001). Metodologi Penelitian Sosial Format-format Kuantitatif dan Kualitatif. Surabaya: Airlangga University Press.

Henrika, Dewi Anindawati. (2013). Teknik Permainan untuk Meningkatkan Kemampuan Mengemukakan Pendapat Siswa. Skripsi. Diterbitkan Universitas Negeri Semarang.

Hidayati, Lie Anita. (2004). Cooverative Learning. Jakarta: Grasindo

Iskandar. (2011). Penelitian Tindakan Kelas. Jakarta: Gaung Persada.

Moloeng, J. Lexy. (2000). Metodologi Penelitian Kualitatif. Bandung: Remaja Rosdakarya

Mulyasa, H.E. (2011). Praktik Penelitian Tindakan Kelas. Bandung: Remaja Rosdakarya.

Murni, Sri. (2012). "Upaya Meningkatkan Keberanian Bertanya Siswa Pada Materi Peta dengan Model Pembelajaran Jigsaw Bagi Siswa Kelas IV SD Negeri 2 Kepanjen Kecamatan Delanggu Kabupaten Klaten Tahun Ajaran 2012/2013”. Skripsi S-1. Surakarta: Fakultas keguruan dan Ilmu Pendidikan Universitas Muhammadiyah Surakarta.

Purwanto, Ngalim. (2008). Prinsip-pronsip dan Teknik Evaluasi Pengajaran. Bandung: Remadja Rosdakarya.

Septawati, Wulan. (2013). "Upaya Meningkatkan Keberanian Bertanya dalam Pembelajaran IPS melalui Strategi Learning Starts with a Question pada siswa Kelas V SD Negeri Sumbersari 01 Tahun 2013." Skripsi-S1 FKIP. Surakarta: Fakultas Keguruan dan Ilmu Pendidikan Universitas Muhammadiyah Surakarta.

Suwarna, dkk. (2005). Pengajaran Mikro Pendekatan Praktis dalam Menyiapkan Pendidik Profesional. Yogyakarta: Tiara Wacana

Tanzeh, Ahmad. (2011). Metodologi Penelitian Praktis. Yogyakarta: Teras.

Tim Penyusun Departemen Pendidikan Nasional. (2008). Kamus Besar Bahasa Indonesia. Jakarta: Balai Pustaka.

Wiratmadja, Rochiati. (2010). Metode Penelitian Tindakan Kelas. Bandung: Remaja Rosdakarya. 